\title{
Enhanced thermophilic bioenergy production from food waste by a two-stage fermentation process
}

\author{
Jaruwan Wongthanate $^{1} \cdot$ Kanda Mongkarothai $^{1}$
}

Received: 28 January 2017 / Accepted: 20 January 2018 / Published online: 31 January 2018

(c) The Author(s) 2018. This article is an open access publication

\begin{abstract}
Purpose The objective of research was emphasized on the optimal conditions (initial $\mathrm{pH}$ and $\mathrm{C} / \mathrm{N}$ ratio) for enhancing bioenergy from food waste by a two-stage fermentation process.

Methods Bioenergy production from food waste was operated by mixed culture under thermophilic temperature in batch reactor. Thermophilic biohydrogen production was optimized in terms of initial $\mathrm{pH}$ (5.0-9.0) and then was optimized in terms of $\mathrm{C} / \mathrm{N}$ ratio (10-50) in the first stage. After that, thermophilic biomethane production was optimized in terms of initial $\mathrm{pH}(6.0-10.0)$ in the second stage.

Results The results revealed that the thermophilic biohydrogen production from food waste at an initial $\mathrm{pH} 7.0$ presented the maximum hydrogen yield of $176.10 \mathrm{~mL} \mathrm{H}_{2} / \mathrm{g}$ COD. At this optimal initial $\mathrm{pH}$, the maximum hydrogen yield of $214.88 \mathrm{~mL}$ $\mathrm{H}_{2} / \mathrm{g}$ COD was achieved at $\mathrm{C} / \mathrm{N}$ ratio 30 . Subsequently, the effluent from the first stage of thermophilic biohydrogen production from food waste under the optimal initial $\mathrm{pH}$ of 7.0 and the optimal $\mathrm{C} / \mathrm{N}$ ratio of 30 was used as a substrate in the second stage of thermophilic biomethane production. Thermophilic biomethane production from hydrogen fermentation effluent provided the maximum methane yield of $310.77 \mathrm{~mL} \mathrm{CH}_{4} / \mathrm{g} \mathrm{COD}$ at initial $\mathrm{pH} 7.0$. At these optimal conditions, COD removal was achieved at $70-90 \%$.

Conclusion Therefore, a two-stage thermophilic fermentation process could effectively enhance biohydrogen and biomethane production, including reduction of organic waste at the same time.
\end{abstract}

Keywords Biohydrogen production $\cdot$ Biomethane production $\cdot$ Food waste $\cdot \mathrm{pH} \cdot \mathrm{C} / \mathrm{N}$ ratio

\section{Introduction}

Hydrogen $\left(\mathrm{H}_{2}\right)$ is recognized as a clean and environmentally friendly energy. It generates only water $\left(\mathrm{H}_{2} \mathrm{O}\right)$ when it is combusted as a fuel or transformed into electricity. The US Department of Energy Hydrogen Program estimated that the provision of hydrogen to the total energy market will increase to $8-10 \%$ by 2025 (Wu et al. 2013). Dark fermentation is a biological hydrogen (biohydrogen) production that utilizes anaerobic bacteria to decay organic materials. This process requires low energy and it does not use light;

Jaruwan Wongthanate

jaruwan.won@mahidol.ac.th

Kanda Mongkarothai

kanda_kann@hotmail.com

1 Faculty of Environment and Resource Studies, Mahidol University, 999 Phutthamonthon 4 Road, Salaya, Phutthamonthon, Nakhon Pathom 73170, Thailand therefore, it rapidly makes $\mathrm{H}_{2}$ production easy to operate) (Wang and Wan 2009). Food waste is a kind of organic waste that can be used as a substrate. It is a carbohydrate-based waste which is the main source for biohydrogen production. Carbohydrate-based waste can provide hydrogen production 20 times higher than protein-based waste and fat-based waste (Show et al. 2012). For biohydrogen production by mixed cultures, a heat shock method is the ultimate and most commonly used pretreatment method of mixed cultures to restrain the activity of $\mathrm{H}_{2}$-consuming bacteria while still conserving the $\mathrm{H}_{2}$-producing bacteria (Valdez-Vazquez and Poggi-Varaldo 2009). During biohydrogen production process, not only is $\mathrm{H}_{2}$ produced as the main product but also volatile fatty acids (VFAs) and alcohols occurred as byproducts (Wei et al. 2010). These byproducts can be used as a substrate for biomethane production (Chu et al. 2012). Therefore, biohydrogen and biomethane production by a two-stage fermentation process has been applied and developed at present (Luo et al. 2011). In a two-stage process, 
$\mathrm{H}_{2}$-producing bacteria and methanogenic bacteria are the main microorganism in biohydrogen (first stage) and biomethane (second stage) production processes, respectively. Fermentation process is a complicated process and is encouraged by various factors. Previous research has investigated the effect of initial $\mathrm{pH}(5.0-8.0)$ and temperature $\left(35-60^{\circ} \mathrm{C}\right)$ on biohydrogen production from food waste. It was found that hydrogen yield was low at the mesophilic temperature in the range of $35-40{ }^{\circ} \mathrm{C}$, while it was higher at thermophilic temperature in the range of $50-55^{\circ} \mathrm{C}$. The extreme temperature of $60^{\circ} \mathrm{C}$ caused inhibition of hydrogen production. Furthermore, $\mathrm{pH}$ is an important factor influencing the growth of a diversity of microorganisms involved in various stages during operation of the process (Chandra et al. 2012). The minimum hydrogen yield was achieved at an initial $\mathrm{pH}$ 5.0, which was not appropriate for $\mathrm{H}_{2}$-producing bacteria. The maximum hydrogen yield was achieved at an initial $\mathrm{pH}$ 7.0, followed by initial pH 8.0 and 6.0, respectively (Nazlina et al. 2009). In biomethane process, $\mathrm{pH}$ outside the range of approximately 6.0-8.5 starts a slowing toxic effect on methanogens. The $\mathrm{pH}$ of the system can rely on the rate at which intermediates are developed during fermentation (Chandra et al. 2012). If the $\mathrm{pH}$ of the waste is outside the optimal range and there is insufficient buffer capacity, the anaerobic process will be inhibited (Raposo et al. 2011). Consequently, it is reasonable to control the $\mathrm{pH}$ value in the first stage lower than that in the second stage of a two-stage biogas plant (Chandra et al. 2012). It is well known that the fermentation process under thermophilic temperature (around $55^{\circ} \mathrm{C}$ ) is more proficient than mesophilic (around $37^{\circ} \mathrm{C}$ ) temperature to produce biogas (Abbasi et al. 2012). However, the other environmental conditions such as $\mathrm{pH}$, $\mathrm{C} / \mathrm{N}$ ratio and others might differently enhance biohydrogen and biomethane production since the dissimilarity of microorganism of each process. Hence, the objective of this research was emphasized on the optimal environmental conditions for a two-stage fermentation process from food waste using mixed cultures including initial $\mathrm{pH}$ and $\mathrm{C} / \mathrm{N}$ ratio in biohydrogen production process (first stage) and initial $\mathrm{pH}$ in biomethane production process (second stage) under thermophilic temperature.

\section{Materials and methods}

\section{Feedstock and seed sludge}

Food waste was taken from a main canteen at Mahidol University (Salaya campus), Nakhonpathom province, Thailand. Hard materials such as animal bones and shells in food waste were removed. The compositions of food waste were $55 \%$ (rice and noodle), 23\% (vegetables), and 13\% (meat) and $9 \%$ (pig, chicken and fish bones) on wet weight (w/w) basis. After that, food waste was ground into small particles by a blender and was screened with a sieve $(2.0 \mathrm{~mm})$. Then, substrate was prepared by mixing food waste and distilled water with a volumetric waste to water ratio of 1:2. Food waste slurry without sterilization was conducted in both stages of experiment. The physical and chemical characteristics of food waste slurry were $\mathrm{pH} 4.7$, total solids (TS) $208,530 \mathrm{mg} / \mathrm{L}$, chemical oxygen demand (COD) $165,330 \mathrm{mg} / \mathrm{L}$, total Kjeldahl nitrogen (TKN) $3870 \mathrm{mg} / \mathrm{L}$, carbohydrate $142,870 \mathrm{mg} / \mathrm{L}$, protein $24,210 \mathrm{mg} / \mathrm{L}$ and fat oil and grease (FOG) 26,630 mg/L (APHA 2012). Anaerobic sludge was taken from the Nonthaburi bio-fertilizer plant in Thailand. The characteristics of seed sludge were $\mathrm{pH} 7.8$, TS 74,810 mg/L, COD 37,330 mg/L, and TKN $1540 \mathrm{mg} / \mathrm{L}$ (APHA 2012). Seed sludge was screened with a sieve $(2.0 \mathrm{~mm})$ to remove large particulate materials. Then, it was heated at $90{ }^{\circ} \mathrm{C}$ for $10 \mathrm{~min}$ to facilitate the growth of sporeforming bacteria and restrain hydrogen-consuming bacteria (Wang and Wan 2008).

\section{Experimental setup}

Batch experiments were conducted in $250 \mathrm{~mL}$ Duran bottles. Each bottle was covered with black plastic to eliminate light. The bioreactor with $200 \mathrm{~mL}$ working volume consisted of $10 \mathrm{~mL}$ nutrient solution, $20 \mathrm{~mL}$ seed sludge and $170 \mathrm{~mL}$ substrate. The nutrient solution contained $40 \mathrm{~g} \mathrm{NaHCO}_{3}, 15 \mathrm{~g} \mathrm{FeSO}_{4} \cdot 7 \mathrm{H}_{2} \mathrm{O}, 5 \mathrm{~g} \mathrm{~K}_{2} \mathrm{HPO}_{4} \cdot 3 \mathrm{H}_{2} \mathrm{O}, 5 \mathrm{~g}$ $\mathrm{NH}_{4} \mathrm{Cl}, 5 \mathrm{~g} \mathrm{NaH}_{2} \mathrm{PO}_{4} \cdot 2 \mathrm{H}_{2} \mathrm{O}, 0.085 \mathrm{~g} \mathrm{MgCl}_{2} \cdot 6 \mathrm{H}_{2} \mathrm{O}$ and $0.004 \mathrm{~g} \mathrm{NiCl}_{2} \cdot 6 \mathrm{H}_{2} \mathrm{O}$ in $1000 \mathrm{~mL}$ distilled water (Wang and Wan 2008). The bioreactor was purged by nitrogen gas for 1 min, capped with a silicone rubber stopper then screw cap, and installed in an air bag. Then, it was placed in a water bath shaker (100 rounds per minute) under thermophilic temperature $\left(55 \pm 2{ }^{\circ} \mathrm{C}\right)$. The experiments were carried out in triplicate.

The optimal initial $\mathrm{pH}$ and $\mathrm{C} / \mathrm{N}$ ratio were investigated in the biohydrogen production process (first stage). Food waste slurry and pretreated seed sludge were added in the batch reactor. Initial $\mathrm{pH}$ values of 5.0, 6.0, 7.0, 8.0 and 9.0 were adjusted with $\mathrm{HCl}$ or $\mathrm{KOH}$. Subsequently, the optimal initial $\mathrm{pH}$ was carried on the experiment of $\mathrm{C} / \mathrm{N}$ ratio. To prepare different $\mathrm{C} / \mathrm{N}$ ratios, $\mathrm{NH}_{4} \mathrm{HCO}_{3}$ and $\mathrm{NH}_{4} \mathrm{Cl}$ were used as a nitrogen source from ammonium salt and $\mathrm{COD}$ value of food waste was used as carbon source to create $\mathrm{C} / \mathrm{N}$ ratio values of 10, 20, 30, 40 and 50 (Kalil et al. 2008). The residue of biohydrogen production under the optimal initial $\mathrm{pH}$ and $\mathrm{C} / \mathrm{N}$ ratio was collected. The physical and chemical characteristics of the residue (hydrogen fermentation effluent) were $\mathrm{pH}$ 6.98, COD $7787 \mathrm{mg} / \mathrm{L}$, TKN $25 \mathrm{mg} / \mathrm{L}$, and $\mathrm{NH}_{3}-\mathrm{N}$ 1986 mg/L (APHA 2012). Hydrogen fermentation effluent and seed sludge were added in the biomethane production process (second stage). Lastly, the optimal initial $\mathrm{pH}$ was 
carried out in the experiment. Initial $\mathrm{pH}$ values were 6.0, 7.0, 8.0, 9.0 and 10.0 and were adjusted with $\mathrm{HCl}$ or $\mathrm{KOH}$.

\section{Analytical method and data analysis}

Biogas volume was measured every $24 \mathrm{~h}$ by a wetted glass syringe sized 50-100 mL. Hydrogen and methane were measured after the experiment was started at $4,6,8,10$, $12 \mathrm{~h}$ and every $24 \mathrm{~h}$ by a gas chromatography system (Varian STAR 3400, USA) equipped with a thermal conductivity detector. The stainless steel packed column was an Alltech, Molesieve 5A 80/100 10'x 1/8". Argon was applied as a carrier gas. The operating temperatures of the interjection, column and detector were 80,50 and $90{ }^{\circ} \mathrm{C}$, respectively. The liquid in the bioreactor was sampled $1 \mathrm{~mL}$ every $48 \mathrm{~h}$ by a plastic syringe. Then, mixed liquor samples from the bioreactor were monitored for $\mathrm{pH}$ and COD analysis after the experiment (APHA 2012). Volatile fatty acid (VFA) was measured before and after the fermentation. The products were sampled for $5 \mathrm{~mL}$ using syringe, and centrifuged at $10,000 \mathrm{rpm}$ for $2 \mathrm{~min}$ to separate solid remaining in the sampled solution. Then, the supernatant was analyzed by a gas chromatography system-flame ionization detector (GCFID), equipped with TG-WAXMS A column. The carrier gas was helium with a flow rate at $3 \mathrm{~mL} / \mathrm{min}$. The operating temperatures of injector and detector were 230 and $250{ }^{\circ} \mathrm{C}$, respectively. The oven temperature was started at $50^{\circ} \mathrm{C}$ for 2 min and then increased to $230{ }^{\circ} \mathrm{C}$ at a rate of $50{ }^{\circ} \mathrm{C}$ per min. Subsequently, the temperature was kept at $230{ }^{\circ} \mathrm{C}$ for 3 min (Wongthanate and Polprasert 2015).

Mass balance equation (Eq. 1) was calculated for cumulative hydrogen or methane production (Elbeshbishy and Nakhla 2012; Wongthanate and Polprasert 2015).

$V_{\mathrm{H}, i}=V_{\mathrm{H}, i-1}+C_{\mathrm{H}, i}\left(V_{\mathrm{G}, i}-V_{\mathrm{G}, i-1}\right)+V_{\mathrm{H}}\left(C_{\mathrm{H}, i}-C_{\mathrm{H}, i-1}\right)$,

where $V_{\mathrm{H}, i}$ and $V_{\mathrm{H}, i-1}$ are the cumulative hydrogen gas volumes (or cumulative methane gas volumes) at the current $(i)$, and the previous time interval $(i-1), V_{\mathrm{G}, i}$ and $V_{\mathrm{G}, i-1}$ are the total biogas volume at the current and the previous time interval, $C_{\mathrm{H}, i}$ and $C_{\mathrm{H}, i-1}$ are the fraction of hydrogen gas (or methane gas) in the headspace at the current and the previous time interval and $V_{\mathrm{H}}$ is the volume of the headspace in the bioreactor.

Modified Gompertz equation (Eq. 2) was calculated for cumulative hydrogen production and cumulative methane production (Elbeshbishy and Nakhla 2012; Wongthanate and Polprasert 2015).

$H=P \times \exp \left\{-\exp \left[\frac{R_{\mathrm{m}} \times e}{P}(\lambda-t)+1\right]\right\}$,

where $H(\mathrm{~mL})$ is the cumulative hydrogen production (or cumulative methane production), $P(\mathrm{~mL})$ is the hydrogen production (or methane production), $R_{\mathrm{m}}(\mathrm{mL} / \mathrm{h})$ is the maximum hydrogen production rate (or maximum methane production rate), $\lambda(\mathrm{h})$ is the lag phase time, $t(\mathrm{~h})$ is the incubation time and $e=2.71828$.

\section{Results and discussion}

\section{Effect of initial pH on thermophilic biohydrogen production}

In this experiment, biogas production, cumulative hydrogen production and hydrogen production rate were $1060.67-2406.00 \mathrm{~mL}, 322.17-1549.57 \mathrm{~mL}$ and 9.18-41.71 mL/h, respectively. Cumulative hydrogen production and COD of food waste were calculated for hydrogen yield ( $\left.\mathrm{mL} \mathrm{H}_{2} / \mathrm{g} \mathrm{COD}\right)$. Hydrogen yields at various initial $\mathrm{pH}$ values under thermophilic temperature are shown in Fig. 1. The curves were plotted with the predicted values by the modified Gompertz equation and were fitted with the observed values of the experiment. The correlation coefficient $\left(R^{2}\right)$ values were approximately 0.98 , which indicated that the modified Gompertz equation could successfully describe the progress of cumulative hydrogen production. All of the experiments presented a lag phase time of $12 \mathrm{~h}$. This duration was a physiological adaptation of hydrogenproducing bacteria that depends on several factors such as $\mathrm{pH}$, temperature, nutrient, germinant availability and others (Valdez-Vazquez and Poggi-Varaldo 2009). As a result, initial $\mathrm{pH}$ had a significant $(p<0.05)$ effect on hydrogen yield under thermophilic temperature. The maximum hydrogen yield (176.10 $\mathrm{mL} \mathrm{H}_{2} / \mathrm{g}$ COD) was obtained at an initial $\mathrm{pH}$ 7.0 , while the minimum hydrogen yield $\left(36.61 \mathrm{~mL} \mathrm{H}_{2} / \mathrm{g}\right.$ COD) was achieved at initial $\mathrm{pH}$ 5.0. Hydrogen yield significantly increased with increasing initial $\mathrm{pH}$ from 5.0 to 7.0. Then, it significantly decreased as the initial $\mathrm{pH}$ increased from 7.0 to 9.0. The result demonstrated that increasing initial $\mathrm{pH}$ could enhance the capability of hydrogen-producing bacteria to produce hydrogen. However, the higher or lower initial $\mathrm{pH}$ value could decrease hydrogen production (Wang and Wan 2009; Wong et al. 2014). In this study, thermophilic biohydrogen production from food waste was significantly obtained at an initial $\mathrm{pH}$ of 7.0. It resembled previous research, in which the maximum hydrogen yield (593 mL/g carbohydrate) was achieved at an initial $\mathrm{pH}$ of 7.0 as well (Nazlina et al. 2009). However, some research has reported the thermophilic biohydrogen production could be achieved at an initial $\mathrm{pH}$ of $6.5\left(1.52 \mathrm{~mol} \mathrm{H}_{2} / \mathrm{mol}\right.$ glucose) (Karadag et al. 2009), and initial $\mathrm{pH}$ in the range of 5.0-5.5 (1.6-1.7 $\left.\mathrm{mol} \mathrm{H}_{2}\right)($ Calli et al. 2009). The difference of these optimal initial $\mathrm{pH}$ values was the result of the various characteristics of substrate and seed sludge, initial $\mathrm{pH}$ range studied, reactor type, nutrients and other factors. Initial $\mathrm{pH}$ value is an important factor since it influences: lag 
Fig. 1 Effect of initial $\mathrm{pH}$ on thermophilic biohydrogen production

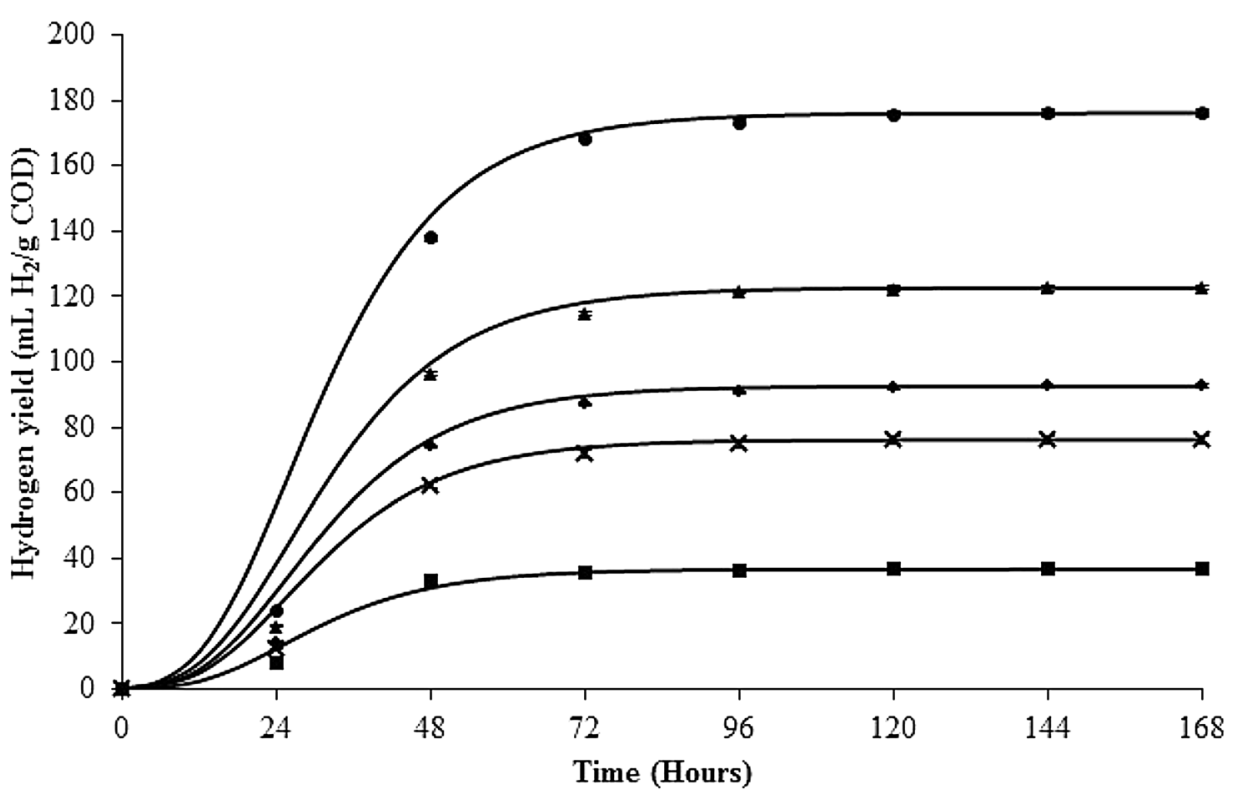

$\rightarrow-\mathrm{pH} 5$ (lag phase $\left.12 \mathrm{~h}, \mathrm{R}^{2} 0.98\right)$
$\rightarrow-\mathrm{pH} 7$ (lag phase $\left.12 \mathrm{~h}, \mathrm{R}^{2} 0.98\right)$
$\rightarrow-\mathrm{pH} 9$ (lag phase $\left.12 \mathrm{~h}, \mathrm{R}^{2} 0.98\right)$ $\rightarrow \mathrm{pH} 6$ (lag phase $12 \mathrm{~h}, \mathrm{R}^{2} 0.98$ )

$\rightarrow$ pH 8 (lag phase $12 \mathrm{~h}, \mathrm{R}^{2} 0.98$ ) phase time, spore germination, bacterial growth and synthesis of enzymes (Sinha and Pandey 2011). The activity of hydrogen-producing bacteria can occur within a $\mathrm{pH}$ range of 5.0-7.5. The accumulation of VFAs caused reduction of the final $\mathrm{pH}$ value in the reactor. In this study, the final $\mathrm{pH}$ values were in the range of 4.02-4.29. The low $\mathrm{pH}$ value and the large concentration of VFAs can inhibit the activity of hydrogen-producing bacteria. In addition, hydrogen is not produced when the $\mathrm{pH}$ value is less than 4.0 (Wei et al. 2010). After the experiment was finished, it was found that the COD of all batch reactors decreased. The maximum COD removal efficiency $(91 \%)$ was obtained at the initial $\mathrm{pH}$ of 7.0, while the minimum COD removal efficiency $(75 \%)$ was obtained at the initial $\mathrm{pH}$ of 5.0. In a dark fermentation process, substrate was decomposed and converted to biogas by microorganisms (Abbasi et al. 2012). Thus, COD removal led to the degradation of organic matter. It conformed to the previous results that substrate degradation efficiency could be improved with an increase of the initial $\mathrm{pH}(6.0-7.0)$ and optimal temperature conditions $\left(37.8^{\circ} \mathrm{C}\right)$, and then it decreased with the higher initial $\mathrm{pH}(8.0-9.0)$ and temperature (40-45 $\left.{ }^{\circ} \mathrm{C}\right)$ (Wang and Wan 2011).

\section{Effect of $\mathrm{C} / \mathrm{N}$ ratio on thermophilic biohydrogen production}

This experiment was investigated at the optimal initial $\mathrm{pH}$ of 7.0. Biogas production, cumulative hydrogen production and hydrogen production rate were $1055.67-5066.67 \mathrm{~mL}$,
351.00-1890.81 mL and 10.69-65.45 mL/h, respectively. Hydrogen yields at various $\mathrm{C} / \mathrm{N}$ ratios by the modified Gompertz equation are shown in Fig. 2. The predicted values by the modified Gompertz equation were well consistent with the observed values, as $R^{2}$ values were 0.99 . The lag phase time was in $8-24 \mathrm{~h}$. The shortest lag phase time of $8 \mathrm{~h}$ was found at $\mathrm{C} / \mathrm{N}$ ratio 30 and 40 . It has been noted that addition of external nitrogen source could enhance bacterial growth and synthesis of hydrogenase (Argun et al. 2008). As a result, $\mathrm{C} / \mathrm{N}$ ratio had a significant $(p<0.05)$ effect on hydrogen yield under thermophilic temperature. The maximum hydrogen yield $\left(214.88 \mathrm{~mL} \mathrm{H}_{2} / \mathrm{g}\right.$ COD) was achieved at $\mathrm{C} / \mathrm{N}$ ratio 30 , while the minimum hydrogen yield (39.89 $\mathrm{mL} \mathrm{H}_{2} / \mathrm{g} \mathrm{COD)} \mathrm{was} \mathrm{achieved} \mathrm{at} \mathrm{C} / \mathrm{N}$ ratio 10 . Hydrogen yield was significantly enhanced with increasing $\mathrm{C} / \mathrm{N}$ ratio from 10 to 30 . Subsequently, it significantly decreased as the $\mathrm{C} / \mathrm{N}$ ratio increased from 30 to 50 . The results indicated that the optimal $\mathrm{C} / \mathrm{N}$ ratio could enhance biohydrogen production. Food waste is a carbohydrate-based waste, in which the main composition is carbon $(\mathrm{C})$, whereas the other nutrients such as nitrogen $(\mathrm{N})$, phosphorus $(\mathrm{P})$ are deficient. Nitrogen is an essential nutrient for microorganisms because it is a component in enzymes, nucleic acids and protein. Therefore, the appropriate amount of the external nitrogen was required for stimulation the activity of hydrogen-producing bacteria and enhancement of biohydrogen production (Sreela-or et al. 2011; Hay et al. 2017). The high $\mathrm{C} / \mathrm{N}$ ratio (shortage of nitrogen) could decrease biohydrogen production because nitrogen will be rapidly consumed and then 
Fig. 2 Effect of $\mathrm{C} / \mathrm{N}$ ratio on thermophilic biohydrogen production

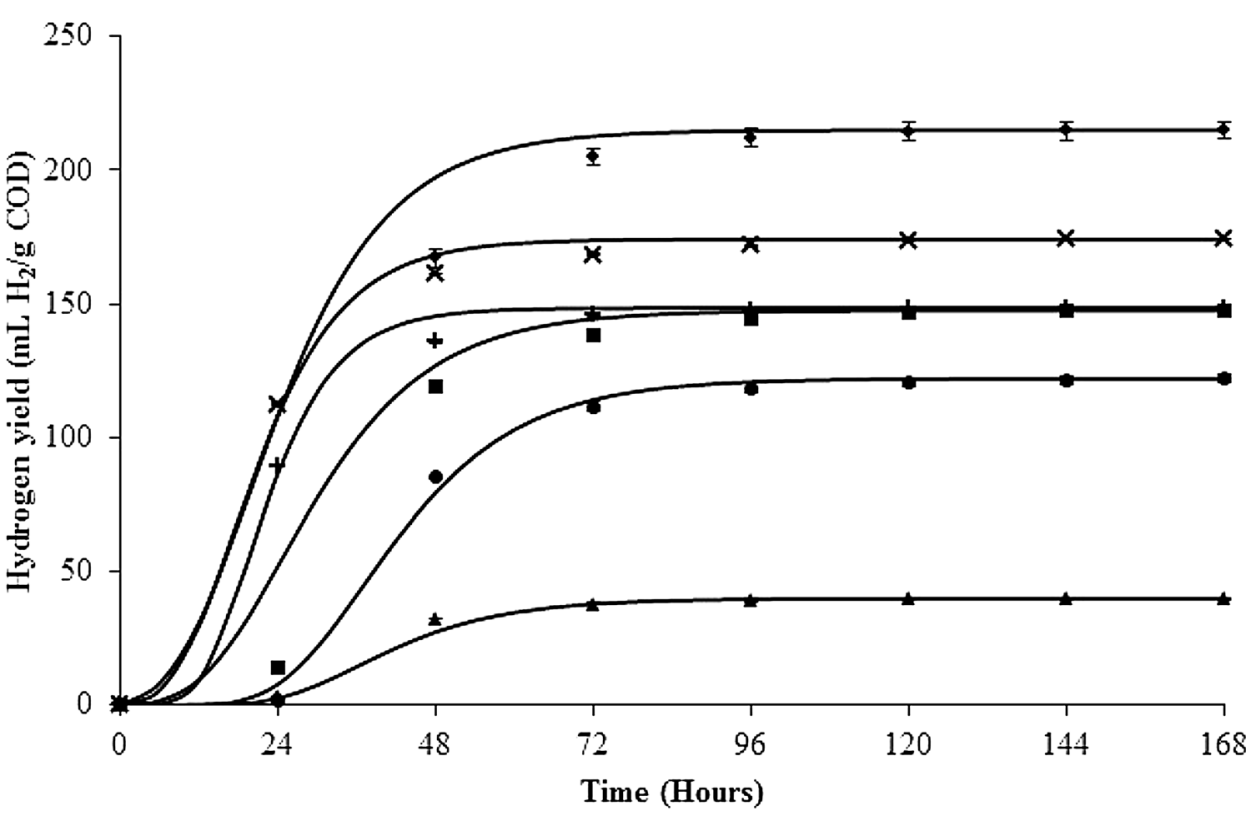

$\rightarrow-$ Control (lag phase $\left.12 h, R^{2} 0.96\right)$
$\rightarrow$ C N 20 (lag phase $\left.24 h, R^{2} 0.99\right)$
$\rightarrow-C / N 40$ (lag phase $8 h, R^{2} 0.99$ )

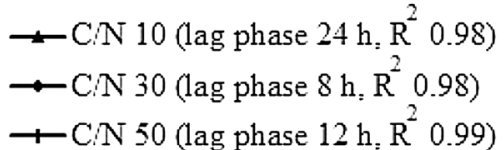

it will be lacking for microbial growth. On other sides, a low $\mathrm{C} / \mathrm{N}$ ratio results in as excess of nitrogen that will be released and accumulated in the form of ammonia (Abbasi et al. 2012). Generally, carbon utilization of microorganism is 25-30 times greater than nitrogen. Thus, a $\mathrm{C} / \mathrm{N}$ ratio of 20-30 is necessary for biological process and $\mathrm{C} / \mathrm{N}$ ratio in the range of 10-45 is suggested for hydrolysis/acidogenesis (Chandra et al. 2012). In this study, thermophilic biohydrogen production from food waste was significantly achieved at a $\mathrm{C} / \mathrm{N}$ ratio of 30 . When compared to the previous research, various optimal $\mathrm{C} / \mathrm{N}$ ratio values were reported because of the difference of substrate and seed sludge, nitrogen source, $\mathrm{C} / \mathrm{N}$ range studied, and other factors. It has been reported that the maximum hydrogen yield $\left(102.63 \mathrm{~mL} \mathrm{H}_{2} / \mathrm{g} \mathrm{VS}\right)$ was obtained from co-digestion of food waste and sludge at a $\mathrm{C} / \mathrm{N}$ ratio of 33 (Sreela-or et al. 2011). Other researches on mesophilic biohydrogen production reported that the maximum hydrogen yield of hydrolyzed wheat starch $(2.84 \mathrm{~mol}$ $\mathrm{H}_{2} /$ mol glucose) was achieved at a $\mathrm{C} / \mathrm{N}$ ratio of 50 (Oztekin et al. 2008), while the maximum hydrogen yield of wheat powder solution ( $281 \mathrm{~mL} \mathrm{H}_{2} / \mathrm{g}$ starch) was achieved at a $\mathrm{C} / \mathrm{N}$ ratio of 200 (Sreela-or et al. 2011). After the experiment finished, the initial $\mathrm{pH}$ of 7.0 decreased to the final $\mathrm{pH}$ in the range of 4.27-6.61. It was mentioned that the $\mathrm{C} / \mathrm{N}$ ratio influenced the final $\mathrm{pH}$ value. The maximum final $\mathrm{pH}$ of 6.61 presented at a $\mathrm{C} / \mathrm{N}$ ratio of 10 , while the minimum final $\mathrm{pH}$ of 4.27 presented at a $\mathrm{C} / \mathrm{N}$ ratio of 50 . Nitrogen will be released in the form of ammonia at a low $\mathrm{C} / \mathrm{N}$ ratio.
The accumulation of excess ammonia caused an increase of $\mathrm{pH}$ in the system and had an adverse effect on the activity of microorganisms (Chandra et al. 2012). The maximum COD removal efficiency $(90 \%)$ was achieved at a $\mathrm{C} / \mathrm{N}$ ratio of 30, while the minimum COD removal efficiency $(43 \%)$ was achieved at a $\mathrm{C} / \mathrm{N}$ ratio of 10 . This study indicated that the $\mathrm{C} / \mathrm{N}$ ratio influenced the hydrogen yield, final $\mathrm{pH}$ value and COD removal in thermophilic biohydrogen production from food waste.

\section{Effect of initial pH on thermophilic biomethane production}

The chemical characteristics of hydrogen fermentation effluent (COD and TKN) showed a high $\mathrm{C} / \mathrm{N}$ ratio (approximately 312). Generally, a $\mathrm{C} / \mathrm{N}$ ratio in the range of 20-30 is considered appropriate for biomethane production (Chandra et al. 2012). Therefore, the hydrogen fermentation effluent was adjusted to a $\mathrm{C} / \mathrm{N}$ ratio around of 25 by addition of $\mathrm{NH}_{4} \mathrm{HCO}_{3}$. Ammonia is considered as a main inhibitor in the biomethane production process. It has been reported that the activity of methanogenic bacteria went down by $56.5 \%$ when the concentration of ammonia ranged between 4051 and $5734 \mathrm{mg} / \mathrm{L}$ (Chen et al. 2008). In this study, the hydrogen fermentation effluent had an ammonia concentration of $1985.86 \mathrm{mg} / \mathrm{L}$. Moreover, the experiment resulted in the production of acetic acid $(14,378.53 \mathrm{mg} / \mathrm{L})$, butyric acid (4978.02 mg/L) and propionic acid (530.11 mg/L) which 
were produced as byproducts from biohydrogen production process. Generally, methanogenic bacteria can consume hydrogen with carbon, formate, methanol and acetic acid as substrates and then convert to methane (Chandra et al. 2012). However, methanol was not found in the hydrogen fermentation effluent.

In this experiment, biogas production, cumulative methane production and methane production rate were 55.67-486.67 mL, 0-411.37 mL and 0-7.66 mL/h, respectively. Cumulative methane production and COD of hydrogen fermentation effluent were calculated based on methane yield production $\left(\mathrm{mL} \mathrm{CH}_{4} / \mathrm{g} \mathrm{COD}\right)$. Methane yields at various initial $\mathrm{pH}$ values under thermophilic temperatures are shown in Fig. 3. The correlation coefficient $\left(R^{2}\right)$ was in the range of $0.97-0.99$, which indicated that cumulative methane production by the modified Gompertz equation was consistent with the experimental results.

The lag phase time was in $20-24 \mathrm{~h}$, which is the duration for adaptation, growth and activity of methanogenic bacteria (Abbasi et al. 2012). No activity of methanogenic bacteria was found at an initial $\mathrm{pH}$ of 6.0. As a result, initial $\mathrm{pH}$ had a significant $(p<0.05)$ effect on methane yield under thermophilic temperatures. The maximum methane yield $\left(310.77 \mathrm{~mL} \mathrm{CH}_{4} / \mathrm{g} \mathrm{COD}\right)$ was obtained at an initial $\mathrm{pH}$ of 7.0, while the minimum methane yield $\left(34.44 \mathrm{~mL} \mathrm{CH}_{4} / \mathrm{g}\right.$ COD) was obtained at an initial $\mathrm{pH}$ of 10.0. Initial $\mathrm{pH}$ is an important factor that can enhance biomethane production. The $\mathrm{pH}$ has a significant influence on the growth of several microorganisms in the four stages of anaerobic digestion that are hydrolysis, acidogenesis, acetogenesis and methanogenesis (Abbasi et al. 2012; Chandra et al. 2012). Most methanogenic bacteria can be active in the optimal $\mathrm{pH}$ range of 6.7-7.5, while hydrogen-producing bacteria can be active at a lower optimal $\mathrm{pH}$ range of 5.2-6.3. However, it has been reported that the population of methanogenic bacteria was affected by the toxicity of the $\mathrm{pH}$ value outside the range of 6.0-8.5. When the $\mathrm{pH}$ is lower than 6.6 , it could unfavorably influence the activity of the methanogenic bacteria and a $\mathrm{pH}$ of 6.2 was toxic to methanogenic bacteria (Raposo et al. 2011; Abbasi et al. 2012; Chandra et al. 2012). In this study, thermophilic biomethane production from hydrogen fermentation effluent was significantly obtained at an initial $\mathrm{pH}$ of 7.0. It resembled previous research on thermophilic biomethane production, in which the maximum methane yields of food waste ( $502 \mathrm{~mL} \mathrm{CH}_{4} / \mathrm{g}$ VS) and organic fraction of municipal solid waste were achieved at an initial $\mathrm{pH}$ of 7.2 (Liu et al. 2009). However, it has been noted that the maximum methane yield of food waste $\left(180 \mathrm{~mL} \mathrm{CH}_{4} / \mathrm{g} \mathrm{VS}\right)$ could be achieve with an initial $\mathrm{pH}$ of 8.1 (Forster-Carneiro et al. 2008). After the experiment finished, the final $\mathrm{pH}$ was in the range of 5.71-8.41. During the biomethane production process, organic acids are produced in the preliminary period thus the $\mathrm{pH}$ value of liquor decreases. Then, the $\mathrm{pH}$ value will increase after nitrogen in the system is digested into ammonia (Abbasi et al. 2012). The maximum COD removal efficiency (70\%) was obtained at the initial $\mathrm{pH}$ of 7.0, while
Fig. 3 Effect of initial $\mathrm{pH}$ on thermophilic biomethane production

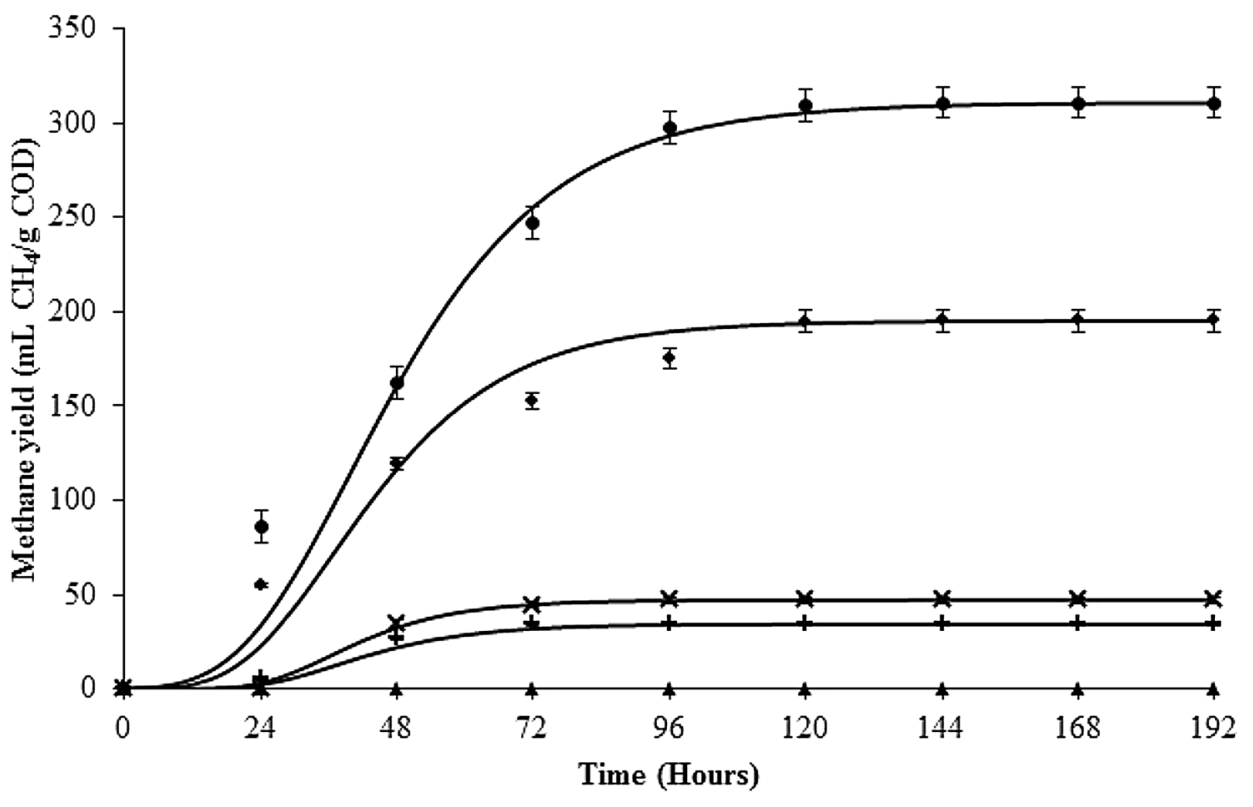

$\rightarrow \mathrm{pH} 6$ (lag phase $0 \mathrm{~h}$ )
$\rightarrow-\mathrm{pH} 8$ (lag phase $20 \mathrm{~h}, \mathrm{R}^{2} 0.97$ )
$\rightarrow-\mathrm{pH} 10$ (lag phase $24 \mathrm{~h}, \mathrm{R}^{2} 0.98$ ) $\multimap \mathrm{pH} 7$ (lag phase $20 \mathrm{~h}, \mathrm{R}^{2} 0.98$ )
$\rightarrow$ pH 9 (lag phase $24 \mathrm{~h}, \mathrm{R}^{2} 0.99$ ) 
Table 1 Experimental kinetic parameters of biogas production from food waste in two-stage fermentation process

\begin{tabular}{|c|c|c|c|c|c|c|c|c|c|c|}
\hline \multirow[t]{2}{*}{ Optimal condition } & \multicolumn{5}{|l|}{ Biohydrogen production } & \multicolumn{5}{|l|}{ Biomethane production } \\
\hline & $\mathrm{H}_{2}$ yield $(\mathrm{mL} / \mathrm{g} \mathrm{COD})$ & $P(\mathrm{~mL})$ & $\lambda(\mathrm{h})$ & $R_{\mathrm{m}}(\mathrm{mL} / \mathrm{h})$ & $R^{2}$ & $\mathrm{CH}_{4}$ yield (mL/g COD) & $P(\mathrm{~mL})$ & $\lambda(\mathrm{h})$ & $R_{\mathrm{m}}(\mathrm{mL} / \mathrm{h})$ & $R^{2}$ \\
\hline $\begin{array}{l}\mathrm{pH} 7.0 \\
\text { Temperature }\left(55^{\circ} \mathrm{C}\right)\end{array}$ & 176.10 & 1549 & 12 & 28.45 & 0.98 & 310.77 & 411.37 & 20 & 7.66 & 0.98 \\
\hline
\end{tabular}

the minimum COD removal efficiency $(15 \%)$ was obtained at the initial $\mathrm{pH}$ of 10.0 . This study indicated that, initial $\mathrm{pH}$ influenced methane yield and COD removal in thermophilic biomethane production from hydrogen fermentation effluent. Furthermore, a $\mathrm{C} / \mathrm{N}$ ratio ranging from 20 to 30 is considered optimum for biomethane production. If the $\mathrm{C} / \mathrm{N}$ ratio is very low, nitrogen will be liberated and accumulated in the form of ammonium ion $\left(\mathrm{NH}_{4}{ }^{+}\right)$. The presence of excess $\mathrm{NH}_{4}{ }^{+}$will increase the $\mathrm{pH}$ of the biodigestate in the digester and consequently a $\mathrm{pH}$ higher than 8.5 will start showing a toxic effect on methanogens. On other sides, if the $\mathrm{C} / \mathrm{N}$ ratio is very high, methanogens will rapidly consume the nitrogen for meeting their protein requirements and will no longer react with the left-over carbon content of the material as well as gas production will be low (Chandra et al. 2012).

Regarding $\mathrm{pH}$ profile during fermentation process, the first stage had an initial $\mathrm{pH}$ of 7.0 and final $\mathrm{pH}$ of 4.19 , while the second stage had initial $\mathrm{pH}$ of 7.0 and final $\mathrm{pH}$ of 5.80. As shown in previous research, methanogenic bacteria have the optimal $\mathrm{pH}$ in the range of $7.0-8.0$, while $\mathrm{H}_{2}$-producing bacteria have a lower optimal $\mathrm{pH}$ (Raposo et al. 2011). However, pH below 6.6 could inhibit the activity of methanogens and a pH of 6.2 could be toxic to methanogens (Chandra et al. 2012). For $\mathrm{H}_{2}$-producing bacteria, the activity of hydrogenase is low when the $\mathrm{pH}$ is lower than 5.2 (Valdez-Vazquez and Poggi-Varaldo 2009). At the optimal initial $\mathrm{pH}$ of 7.0 under thermophilic temperature, the experimental kinetic parameters of cumulative biohydrogen and biomethane production from food waste in two-stage fermentation process are presented in Table 1.

A two-stage fermentation process is a separation of acidogenesis/acetogenesis and methanogenesis for biohydrogen production in the first stage and biomethane production in the second stage, respectively. Acidogenesis/acetogenesis produces hydrogen and carbon dioxide as the main gas products and provides VFAs as the byproducts. Then, a part of the VFAs and other biodegradable residues from the first stage will be converted into methane and carbon dioxide by methanogenesis. There are several advantages from this process such as, enhanced efficiency of substrate digestion and COD removal, high biogas yield, high energy recovery and reduction of the concentration of VFAs in the final product (Gioannis et al. 2013; Nathao et al. 2013). As previous research, biohydrogen and biomethane production from food industry wastes by a two-stage fermentation process was investigated at an initial $\mathrm{pH}$ of 7.0 under the mesophilic temperature $\left(35 \pm 1{ }^{\circ} \mathrm{C}\right)$. The hydrogen recovery, methane recovery and total gas recovery were in the range of 3.40-12.60, 52.30-69.50, and 61.20-75.00\%, respectively (Giordano et al. 2011). Moreover, carbon dioxide and carbon monoxide emission from a two-stage fermentation process are less than a single stage fermentation process (Luo et al. 2011). Thus, a two-stage fermentation process is an environmentally friendly process.

\section{Conclusions}

This study demonstrated that thermophilic biohydrogen production from food waste was achieved at the optimal environmental conditions of initial $\mathrm{pH}$ of 7.0 and $\mathrm{C} / \mathrm{N}$ ratio of 30. Hydrogen fermentation effluent could be used as a substrate for thermophilic biomethane production, which was obtained at the optimal initial $\mathrm{pH}$ of 7.0. At these optimal conditions, COD removal efficiency could be reached in the range of $70-90 \%$. Therefore, a two-stage process of food waste at optimal condition can enhance the bioenergy production and is feasible to treat organic matter in a controlled system.

Acknowledgements This study was supported the grant by National Research Council of Thailand (MU-IRB 2013/018.0503). Authors express our greatest thanks to Associate Professor Dr. Benjaphorn Prapagdee and Assistant Professor Dr. Achara Ussawarujikulchai of Mahidol University, Thailand for their helpful suggestions. We also thank Dr. Thomas Neal Stewart for editing the English language.

Open Access This article is distributed under the terms of the Creative Commons Attribution 4.0 International License (http://creativeco mmons.org/licenses/by/4.0/), which permits unrestricted use, distribution, and reproduction in any medium, provided you give appropriate credit to the original author(s) and the source, provide a link to the Creative Commons license, and indicate if changes were made.

\section{References}

Abbasi T, Tauseef SM, Abbasi SA (2012) Anaerobic digestion for global warming control and energy generation-an overview. Renew Sust Energy Rev 16:3228-3242. https://doi.org/10.1016/j. rser.2012.02.046 
APHA/AWWA/WPCF (2012) Standard methods for the examination of water and wastewater, 22nd edn. American Public Health Association, Washington, DC

Argun H, Kargi F, Kapdan IK, Oztekin R (2008) Biohydrogen production by dark fermentation of wheat powder solution: effect of $\mathrm{C} / \mathrm{N}$ and $\mathrm{C} / \mathrm{P}$ ratio on hydrogen yield and formation rate. Int $\mathrm{J}$ Hydrogen Energy 33:1813-1819. https://doi.org/10.1016/j.ijhyd ene.2008.01.038

Calli B, Chung LC, Arslan D, Vanbroekhoven K (2009) Hydrogen production potential in thermophilic mixed fermentation. J Environ Sci Health 44(1):78-86. https://doi.org/10.1080/1093452080 2515418

Chandra R, Takeuchi H, Hasegawa T (2012) Methane production from lignocellulosic agricultural crop wastes: a review in context to second generation of biofuel production. Renew Sust Energy Rev 16:1462-1476. https://doi.org/10.1016/j.rser.2011.11.035

Chen Y, Cheng JJ, Creamer KS (2008) Inhibition of anaerobic digestion process: a review. Bioresour Technol 99:4044-4064. https:// doi.org/10.1016/j.biortech.2007.01.057

Chu CF, Xu KQ, Li YY, Inamori Y (2012) Hydrogen and methane potential based on the nature of food waste materials in a twostage thermophilic fermentation process. Int J Hydrogen Energy 37:10611-10618. https://doi.org/10.1016/j.ijhydene.2012.04.048

Elbeshbishy E, Nakhla G (2012) Batch anaerobic co-digestion of proteins and carbohydrates. Bioresour Technol 16:170-178. https:// doi.org/10.1016/j.biortech.2012.04.052

Forster-Carneiro T, Perez M, Romero LI (2008) Thermophilic anaerobic digestion of source-sorted organic fraction of municipal solid waste. Bioresour Technol 99:6763-6770. https://doi. org/10.1016/j.biortech.2008.01.052

Gioannis GD, Muntoni A, Polettini A, Pomi R (2013) A review of dark fermentative hydrogen production from biodegradable municipal waste fractions. Waste Manag 33:1345-1361. https://doi. org/10.1016/j.wasman.2013.02.019

Giordano A, Cantu C, Spagni A (2011) Monitoring the biochemical hydrogen and methane potential of the two-stage dark-fermentative process. Bioresour Technol 102:4474-4479. https://doi. org/10.1016/j.biortech.2010.12.106

Hay JXW, Wu TY, Juan JC, Jahim JM (2017) Effect of adding brewery wastewater to pulp and paper mill effluent to enhance the photofermentation process: wastewater characteristics, biohydrogen production, overall performance, and kinetic modeling. Environ Sci Pollut Res. https://doi.org/10.1007/s11356-017-8557-9

Kalil MS, Alshiyab HS, Yusoff WMW (2008) Effect of nitrogen source and carbon to nitrogen ratio on hydrogen production using $C$. acetobutylicum. Am J Biochem Biotechnol 4:393-401. https:// doi.org/10.3844/ajbbsp.2008.393.401

Karadag D, Makinen AE, Efimova E, Puhakka JA (2009) Thermophilic biohydrogen production by an aerobic heat treated-hot spring culture. Bioresour Technol 98:5790-5795. https://doi.org/10.1016/j. biortech.2009.06.035

Liu G, Zhang R, El-Mashad HM, Dong R (2009) Effect of feed to inoculum ratios on biogas yields of food and green wastes. Bioresour Technol 100:5103-5108. https://doi.org/10.1016/j.biort ech.2009.03.081

Luo G, Xie L, Zhou Q, Angelidaki I (2011) Enhancement of bioenergy production from organic wastes by two-stage anaerobic hydrogen and methane production process. Bioresour Technol 102:8700 8706. https://doi.org/10.1016/j.biortech.2011.02.012

Nathao C, Sirisukpoka U, Pisutpaisal N (2013) Production of hydrogen and methane by one and two stage fermentation of food waste. Int J Hydrogen Energy 38:15764-15769. https://doi.org/10.1016/j. ijhydene.2013.05.047
Nazlina HMY, Nor Aini AR, Ismail F, Yusof MZM, Hassan MA (2009) Effect of different temperature, initial $\mathrm{pH}$ and substrate composition on biohydrogen production from food waste in batch fermentation. Asian J Biotechnol 1:42-50. https://doi.org/10.3923/ ajbkr.2009.42.50

Oztekin R, Kapdan IK, Kargi F, Argun H (2008) Optimization of media composition for hydrogen gas production from hydrolyzed wheat starch by dark fermentation. Int J Hydrogen Energy 33:40834090. https://doi.org/10.1016/j.ijhydene.2008.05.052

Raposo F, De la Rubia MA, Fernandez-Cegri V, Borja R (2011) Anaerobic digestion of solid organic substrates in batch mode: an overview relating to methane yields and experimental procedures. Renew Sust Energy Rev 16:861-877. https://doi.org/10.1016/j. rser.2011.09.008

Show KY, Lee DJ, Tay JH, Lin CY, Chang JS (2012) Biohydrogen production: current perspectives and the way forward. Int $\mathrm{J}$ Hydrogen Energy 37:15616-15631. https://doi.org/10.1016/j. ijhydene.2012.04.109

Sinha P, Pandey A (2011) An evaluative report and challenges for fermentative biohydrogen production. Int J Hydrogen Energy 36:7460-7478. https://doi.org/10.1016/j.ijhydene.2011.03.077

Sreela-or C, Imai T, Plangklang P, Reungsang A (2011) Optimization of key factors affecting hydrogen production from food waste by anaerobic mixed cultures. Int J Hydrogen Energy 36:1412014133. https://doi.org/10.1016/j.ijhydene.2011.04.136

Valdez-Vazquez I, Poggi-Varaldo HM (2009) Hydrogen production by fermentative consortia. Renew Sust Energy Rev 13:1000-1013. https://doi.org/10.1016/j.rser.2008.03.003

Wang J, Wan W (2008) Effect of temperature on fermentative hydrogen production by mixed cultures. Int $\mathrm{J}$ Hydrogen Energy 33(20):5392-5397. https://doi.org/10.1016/j.ijhyd ene.2008.07.010

Wang J, Wan W (2009) Factors influencing fermentative hydrogen production: a review. Int J Hydrogen Energy 34:799-811. https://doi. org/10.1016/j.ijhydene.2008.11.015

Wang J, Wan W (2011) Combined effects of temperature and $\mathrm{pH}$ on biohydrogen production by anaerobic digestion sludge. Int $\mathrm{J}$ Hydrogen Energy 35:3896-3901. https://doi.org/10.1016/j.biomb ioe.2011.06.016

Wei J, Liu ZT, Zhang X (2010) Biohydrogen production from starch wastewater and application in fuel cell. Int J Hydrogen Energy 35:2949-2952. https://doi.org/10.1016/j.ijhydene.2009.05.035

Wong YM, Juan JC, Ting A, Wu TY (2014) High efficiency biohydrogen production from glucose revealed in an inoculum of heat-pretreated landfill leachate sludge. Energy 72:628-635. https ://doi.org/10.1016/j.energy.2014.05.088

Wongthanate J, Polprasert C (2015) Immobilized biofilm in thermophilic biohydrogen production using synthetic versus biological materials. Braz Arch Biol Technol 58(1):123-129. https://doi. org/10.1590/S1516-8913201502895

Wu TY, Mohammad AW, Lim SL, Lim PN, Hay JXW (2013) Recent advances in the reuse of wastewaters for promoting sustainable development. In: Sharma SK, Sanghi R (eds) Wastewater reuse and management. Springer Netherlands, Dordrecht, pp 47-103. https://doi.org/10.1007/978-94-007-4942-9_3

Publisher's Note Springer Nature remains neutral with regard to urisdictional claims in published maps and institutional affiliations. 